\title{
Educational expansion, occupational closure and the relation between educational attainment and occupational prestige over time
}

\section{Corresponding author:}

Markus Klein

University of Strathclyde

markus.klein@strath.ac.uk

markus.klein@ed.ac.uk

\begin{abstract}
This paper considers changes in the association between educational attainment and occupational prestige in Germany over time. We argue that the link between attainment and occupational prestige has become weaker over time because of compositional changes in graduate occupational destinations. Prior to higher education expansion, the small elite group of graduates tended to access the occupationally closed and thus more prestigious professions on graduation. As higher education participation expanded, however, an increasing proportion of graduates found employment in less prestigious and more diverse graduate jobs. The results confirm our theoretical expectations. The association between educational attainment and occupational prestige has decreased over time as graduates entered a broader range of jobs and their relative advantage over those with lower levels of qualifications decreased. This can, in fact, be attributed to a merely compositional change among graduates' occupational destinations from prestigious professions towards less prestigious free-market graduate occupations.
\end{abstract}

\section{Keywords}

Returns to education, Occupational prestige, Occupational closure, Educational expansion, Professions, Germany 


\section{Introduction}

In the social mobility literature, occupational attainment is commonly measured either in terms of class destinations (e.g. Breen 2004) or occupational prestige/status scales (e.g. Blau and Duncan 1967). According to Max Weber's work (1972 [1922]), however, class and prestige are distinct concepts representing different forms of social stratification. While classes reflect the social relations in economic life, prestige is a symbolic sign of the degree of social honour attached to particular social positions. The concept of social class is based on differences in employment relations (as operationalised in the EGP class schema, see Goldthorpe 2007). In contrast, occupational prestige is determined by occupational closure, that is, institutionalised barriers to entering particular occupations (Weeden and Grusky 2005).

This conceptual distinction has theoretical implications for the association between education and occupational positions over time. Changes in the association between education and social class destinations may be different to that between education and occupational prestige. The relationship between an individual's educational qualification and class destination (occupational attainment measured in terms of EGP classes) depends on the relative value that employers attach to education in job allocation processes (Jackson et al. 2005). In many European countries, this association declined over time (Breen 2004). The association between education and occupational prestige, however, is strongly determined by the degree of occupational closure via educational certificates. In this paper, we argue that the link between educational attainment and occupational prestige declined over time irrespective of any changes in the role of education in job allocation.

Prior to educational expansion, university graduates mainly entered professions, such as law or medicine, which are defined by a high degree of self-regulation and strong market shelters against competition and market forces (Timmermans, 2008; Lane et al., 2002). ${ }^{1}$ Since access to these positions is restricted to license-holders, professions are more prestigious than 
free-market positions. Over the course of higher education expansion, however, an increasing share of university graduates did not access these prestigious professions but instead entered a variety of positions in other occupational segments (e.g. the administrative, managerial and service sectors), particularly in private industry. These new emerging graduate occupations are less restricted by occupational closure than the professions and thus necessarily involve lower levels of prestige. Because of this shift in graduate employment profiles, the relationship between educational attainment and occupational prestige became weaker over time. High levels of prestige for all graduates could no longer be guaranteed, even if salariat class positions (EGP I and II in the Goldthorpe class schema) expanded in line with higher educational expansion and the role of educational qualifications in accessing these positions remained unchanged.

This scenario not only affects graduates' labour market rewards but also has implications for intergenerational social mobility. The greater heterogeneity in labour market returns for graduates potentially leads to greater social inequalities among degree holders. Even if higher education expansion reduced class of origin differences in the attainment of a degree, students with a salariat class background would still be able to differentiate themselves from students with intermediate and working class backgrounds by choosing fields of study that lead into the professions, thus maintaining advantages in terms of prestige.

In order to test the assumption of a declining association between education and occupational prestige, we concentrate our analysis on Germany. First, occupational closure in Germany is historically strong, i.e. access to the professions is restricted to individuals with state-certified licences obtained after university education. Second, higher education expansion in Germany has been weak by international comparison (OECD 2013) and thus represents a conservative test for the theoretical predictions. Third, in contrast to other European countries, the association between educational qualifications and class destinations has been found to 
remain rather stable in Germany (Klein 2011). Hence, we can identify whether the association with educational attainment developed differently when considering occupational prestige rather than occupational classes.

The following sections introduce the different concepts of social class and prestige used in the analyses and their implications for the relationship between education and occupational prestige over time. Afterwards, we provide information on the data, measurement of variables and analytic strategy before showing the results. The paper ends with a summary and discussion in light of the hypothesis.

\section{The conceptual distinction between class and prestige}

Weber (1972 [1922]: 531-540) treats class and prestige as distinct forms of social stratification that impact an individual's life chances through different mechanisms. Classes are not communities ('Klassen sind keine Gemeinschaften'), but simply exist when 'a number of people have in common a specific causal component of their life chances' (Weber 1972 [1922]: 532). This causal component reflects economic interests that are expressed under market principles ('Klassenlage'). Thus, the class structure accrues from social relations in economic life, i.e. one's class position ultimately describes one's (labour) market position. The economic situation offers members of a different class different opportunities and constraints that in turn determine class members' goals and interests, eventually leading to different life choices. Classes have a strong impact on their members, irrespective of members' class awareness and thus do not need to represent real collectivities formed by processes of socialisation or social closure. Furthermore, they cannot always be hierarchically ordered: While members of the salariat class are clearly advantaged in terms of their economic situation and the working class disadvantaged, ordering the intermediate classes is less simple (Chan and Goldthorpe 2007).

Unlike class positions, status groups ('Stände') represent communities and describe the degree of social honour attached to members' common attributes. This distribution of social 
honour determines the social order of a society. Social honour is not necessarily based on achievement, wealth, productive assets or authority but rather manifests itself in differing lifestyles. Everyone who desires to be part of a certain status group has to share common attributes with other group members. The status order is based on the monopolisation of ideal and physical goods or chances and relies on distance and exclusiveness. Monopoly tendencies appear because social collectivities seek to restrict access to resources and opportunities to a limited number of eligible personnel and thus close economic opportunities for individuals not belonging to the group, thereby maximising their rewards (Parkin 1979: 44). High status groups block free market developments and establish closed positions (Weber 1972 [1922]: 23-25; 201-207) to preserve the existing social order.

In modern societies, social closure is less commonly based on ascribed attributes but more frequently on individual traits such as property ownership or educational certificates (Collins 1979; Parkin 1979). Social closure is particularly pronounced among communities whose members gain specific qualities - e.g. certificates or official positions - via education, teaching or practice. Prestige is thus most commonly based on occupation (Chan and Goldthorpe 2007). Occupational groups have a strong interest in restricting the supply of job seekers and monopolising their consumption of ideal, social and economic goods, duties and lifestyles. ${ }^{2}$ The smaller and more exclusive the occupational group is, the larger the prestige attached to membership to this group (Weber 1972 [1922]: 206). Occupational prestige - as income or any other reward - can be seen as monopoly rent that increases 'the returns on the asset over what it would have generated in the absence of a monopoly' (Sørensen 2000: 23). Thus, the degree of occupational closure shapes the prestige order in modern societies.

\section{Educational credentialing, licensing and occupational closure}


Occupational closure is established by legal, technical or social barriers that artificially restrict the number of individuals that are able to perform the tasks being provided by an occupation (Freidson 1994: 80-91; see also Parkin 1979: 44-71). The restriction of supply is at the core of Weber's definition of social closure. Weeden (2002) presents two strategies of restricting the supply that are based on educational attainment: educational credentialing and licensing.

Educational credentialing refers to markers of knowledge such as educational certificates used to facilitate employers' selection procedures. 'Credentialism is a form of closure designed to control or monitor entry to key positions in the division of labour' (Parkin 1979: 48). As a consequence, closure in the educational system produces occupational closure in the labour market (Bol and Weeden 2012: 7). Educational certificates do not necessarily have to indicate the acquisition of 'real' skills; whether this closure strategy is useful mainly relies on organisational rules, norms and hiring practices among gatekeepers. In turn, these hiring practices depend on the national institutional setting (such as the education and training system and occupational structure). ${ }^{3}$

By contrast, licensing is a state certification, which grants actors permission to enter an occupation only once individuals have obtained the required occupational title (Kleiner 2006; Kleiner and Krueger 2010). Licensing thus involves imposing legal controls and establishes state-sanctioned quasi-monopolies (Freidson 1994: 83). This strong form of occupational closure is particularly pronounced in the professions. The crucial difference between professions and occupations that rely on weaker forms of occupational closure is that the former seek to establish a legal monopoly over the provision of their services (Parkin 1979: 57). Professions as 'traditional graduate jobs were those for which a degree was essentially a prerequisite' (Elias and Purcell 2004: 61). Thanks to licensing, the professions have a unique labour market position that shields their workers from all kinds of market forces (Timmermans 
2008). Licensing practices for restricting access to the professions are justified by the argument that these occupations provide important public goods. The proper exercise of professional activity would be best guaranteed by state-approved training because professions require a high level of competence and misbehaviour is difficult to monitor (Law and Sukkoo 2005). Professions are more successful in creating legal barriers since they claim that due to the necessity of formal, abstract knowledge 'only members of the occupation possess the skill or qualification, by virtue of their occupational training, to perform it [occupational task] properly or reliably' (Freidson 1994: 87; see also Abbott 1988).

These homogeneity-inducing mechanisms of occupational closure via licensing and elitist training rites mean that professionals are not only able to monopolise their work but also to generate distinct cultures and reputations (Collins 2004; Weeden and Grusky 2005). Formal knowledge and science are commonly recognised attributes in a society that transcend group boundaries and thus represent the institutional realm of shared values and beliefs (Zhou 2005). Based on these attributes, the professions legitimate their claims to be placed at the top of the occupational prestige ranking.

\section{The German case}

Germany is commonly characterised as an occupational labour market (e.g. Marsden 1990) where tight linkages between educational qualifications and occupational positions exist. Job applicants mainly enter specific occupational areas and typical career paths reflecting the occupational skills they acquired in the education and training system. Hence, Germany provides an institutional setting where the closure strategy of educational credentialing is particularly pronounced, i.e. employers strongly rely on educational certificates in their hiring decisions.

More importantly, Germany can be regarded as a strong case for licensing as 'the state guaranteed that university schooling defined the professions' (Abbott 1988: 197). In contrast, 
for instance, to the UK, where professions developed within professional associations outside the university, state certification was the basis for professions in Germany from early on and associations only emerged afterwards (Lane et al. 2002; Neal and Morgan 2000). Historically, the German state regarded it as its duty to restrict access to professional activities and uphold performance standards via strict examination procedures. Thanks to this tradition for licensing, German universities teach theoretical skills and undertake state-controlled examinations in professional programmes, while the state is responsible for practical training and examination in a second educational stage ('Vorbereitungsdienst'). The state, in cooperation with the university, certifies a degree ('Staatsexamen') that provides graduates with the necessary licence to work in traditional professions as doctors, prosecutors, solicitors or teachers. Access to free-lance professions (e.g. architects, psychotherapists or tax representatives) that does not require a state-certified licence is strongly regulated by professional associations. As public bodies, they obtain permission from the state to organise and administer themselves and to undertake legislative actions. Thanks to this autonomy, they are allowed to stipulate educational requirements and award occupational titles. Due to these rights, access to freelance professions is more or less equally dependent on university education as access to stateadministered professions. For most of the professions (doctor, dentist, psychotherapist, vet, pharmacist, lawyer, patent agent, auditor, chartered accountant, tax accountant or tax representative) the unauthorised use of the official title is even punishable under criminal law (Article $\S 132$ a German Criminal Code). ${ }^{4}$ Overall, professional employment is characterised by two dominant features: self-recruitment and self-regulation (Brown 2001).

Likewise, early $18^{\text {th }}$ century Prussia's state bureaucracy established a recruitment and promotion system where a university degree is a necessary requirement for access to the higher ranks of the public service (Fischer and Lundgreen 1975). Pursuing an academic career in Germany is impossible without obtaining a $\mathrm{PhD}$. Other than in the private industry, university 
graduates do not have to compete with lower educated job seekers for high-skilled occupations in the public service. ${ }^{5}$

\section{Occupational closure and higher education expansion}

Since university graduates have the exclusive licences to enter the professions, occupational prestige was strongly associated with university education in Germany. In the early stages of higher education expansion, a small elite group of university graduates mainly entered fields of study that provided access to the professions. Thus, they had, on average, an exceptionally high occupational prestige compared to groups with lower educational attainment. Consequently, the relationship between educational attainment and occupational prestige in Germany was exceptionally high (Müller 2001).

However, educational expansion may have changed this relationship. Access to top levels of the occupational hierarchy is not only dependent on one's own educational attainment but on how much you achieve relative to other job candidates (Brown 2013; Dore 1976). In this sense, professional qualifications can be regarded as a 'positional good' (Hirsch 1977). Positional conflict between graduates for access to the prestigious professions intensified as participation in higher education expanded. Not all graduates were able to acquire a university degree that provides a licence to work in the professions.

In the context of higher education expansion, professions attempt to minimise the number of professionals by increasing educational requirements or restricting access to the acquisition of the license in order to sustain their rewards (Collins 1979). Though, this scenario largely depends on the power of professional groups to establish their exclusionary criteria (Jonsson 1996). In the German corporatist system, the state continues to be responsible for the administration of the professions and acts in their interests (Leuze 2007). The German states (Länder) and single universities are allowed to request a numerus clausus in order to restrict access to popular fields, mainly professions, if demand exceeds the supply of university slots. 
At present, medicine, veterinary medicine, dentistry and pharmacology require a central numerus clausus for all their courses of studies. Admission criteria at the local and national level are the GPA (grade point average) in the upper secondary certificate ('Abitur'), waiting periods and universities' own selection procedures. ${ }^{6}$

Likewise, a steadily increasing demand for the traditional professions seems to be rather unrealistic in modern society. According to the Skill-Biased Technological Change (SBTC) hypothesis, the increase in labour demand for high-skilled relative to low-skilled workers is mainly driven by technical progress and the spread of computer technology (e.g. Autor et al. 2003). Hence, not every new university graduate needs to become, for instance, a doctor, lawyer or teacher amidst higher education growth. Since the expansion of mass higher education involves a stronger demand for labour in the (higher) education system, the public service was initially able to absorb the self-generated production of qualifications in high-rank public service positions in Germany (Becker 1993; Blossfeld 1985). Over time, however, the public service has shed labour and high-skilled positions within this segment have not expanded. Occupational upgrading in Germany mainly took place in administrative, managerial or service sector occupations in private industry (Klein 2011). Since potential students factor in structural shifts in the labour market in deciding which specific field to study, Abitur-holders increasingly opted for fields in greater demand (e.g. business studies). Likewise, an expansion in take-up of popular fields of study may also act as a catalyst for an upgrading in matching occupational segments (Gangl 2003: 275). Accordingly, the private sector became an increasingly important employer among university graduates in Germany (Schubert and Engelage 2006).

As a consequence of educational expansion, an increasing share of university graduates was not channelled into the professions but had to compete with potentially lower educated leavers for other occupational positions. Since non-professional occupational positions do not 
require state-certified licences and thus are, in principle, open to all job seekers, they are necessarily not as prestigious as the professions. Even if occupational upgrading was able to absorb the increasing number of university graduates into 'appropriate' graduate occupations (i.e. the salariat class), the new high-skilled occupations would be open, free-market positions with inherently lower occupational prestige (Collins 2004: 79). Since mechanisms of occupational closure such as licensing operate at the occupational level, prestige is not attached to 'big' social classes and prestige differences within the salariat class exist (Weeden and Grusky 2005).

Based on these theoretical considerations, the hypothesis is as follows:

Given higher education expansion and changes in graduate occupational destinations, the association between educational attainment and occupational prestige decreased over time in Germany.

\section{Data, variables and analytic strategy}

\subsection{Data}

For the purpose of our analysis, we use a series of annually repeated cross-sectional surveys, the Microcensus, covering one per cent of the German households. Concentrating on the economically active population in West Germany, we use the available Scientific-Use-Files $1976,1978,1980,1982,1985,1987,1989,1991,1993$ and 1995-2008. The analysis is further restricted to labour market entrants and separately conducted for men $(\mathrm{N}=204.781)$ and women $(\mathrm{N}=174.776){ }^{7}$ The same data and sample have previously been used to assess changes in the relationship between educational attainment and EGP class destinations (Klein 2011).

\subsection{Variables}

Occupational prestige is measured according to the Magnitude Prestige Scale to the explicitly referring to the German occupational structure (Wegener 1985; Frietsch and Wirth 2001). In contrast to providing predetermined answer categories for linking prestige to 
occupations (e.g. Nakao and Treas 1994; Treiman 1977), it uses a direct scaling, the psychophysical magnitude estimation technique. With this technique, respondents gave implicit ratio judgments about a series of stimuli by evaluating the prestige of 50 occupations compared to the standard of electricians. In a second step, this method estimates the prestige of all other occupations by regressing the Status Attainment Scale (Sørensen 1977; Sørensen 1979) on the 50 subjective prestige scores. This status scale measures occupations by their degree of closure and thus validates the subjective occupational scores in terms of a Weberian interpretation of prestige. Since both measures were highly correlated, the subjective prestige scale can be regarded as a social order in terms of degree of occupational closure. Hence, this prestige scale represents Weber's notion of social honour and thus closely links theory to empirical analysis.

Educational attainment is measured with a six-category version of the CASMIN educational classification which was developed for comparative social mobility research (Brauns and Steinmann 1999; Lechert et al. 2006). This classification is based on educational qualifications and differentiates between $1 \mathrm{ab}$ (primary education or lower secondary qualification), 1c (lower secondary qualification plus apprenticeship), 2ab (intermediate secondary qualification), 2c (upper secondary qualification (Abitur)), 3a (polytechnics (Fachhochschule)) and 3b (university). We additionally control for citizenship (German, West European, Italian, Greeks/FSU (Former Soviet Union) and Others) in our analyses.

\subsection{Analytic strategy}

In the empirical analysis, we conduct OLS regressions of occupational prestige on educational attainment for every survey year. Measuring occupations on a hierarchical scale allows us to use the coefficient of determination $\left(\mathrm{R}^{2}\right)$ as an indicator of changes in the extent to which educational attainment predicts occupational prestige. Subsequently, we explore potential mechanisms for any such changes in greater detail. Three different developments may have 
contributed to a changing proportion of variance explained over time. First, changes in $\mathrm{R}^{2}$ may be attributed to changes in intergroup differences: the differences between CASMIN educational groups in average occupational prestige may differ over time. Second, intragroup variations may have changed over time, i.e. the prestige scores within CASMIN educational groups became more homogeneous or heterogeneous. Third, changes in $\mathrm{R}^{2}$ may result from group composition shifts. The proportion of certificate-holders that strongly deviate from the grand mean may increase (or decrease), thereby changing the magnitude of between-group variance explained. At the same time, homogenous educational groups may grow in size, thereby affecting within-group (residual) variance.

A reduction in the association between education and occupational prestige could be explained by compositional changes in university graduates' occupational destinations from occupationally closed professions to open graduate occupations. In order to test our hypothesis, we consider some counterfactual scenarios. After each of these manipulations, we recalculate the variance explained by educational attainment for every survey year and compare the results to those obtained from the observed data in reality.

In the first scenario, we test whether changes in access to the salariat class (EGP I and II) can account for changes in the link between education and occupational prestige. ${ }^{8}$ Is the increasing proportion of overeducated university graduates - those who work in intermediate and working class positions (EGP III-VII) - responsible for a reduced association? We ask how trends in the predictive value of educational attainment would look if university graduates always found employment in 'appropriate' graduate occupations, i.e. the salariat class. Therefore, we exclude university graduates who attain intermediate and working-class positions at all points in time. Even though all university graduates are assumed to find employment in 'appropriate' graduate occupations, the association should have nevertheless declined. 
In the second scenario, we exclude the professions and ask how trends in the predictive value of educational attainment would look if positions restricted by occupational closure via licensing had never existed. If the association remained stable in this counterfactual world, this would provide support for our hypothesis of an inevitable decline due to a decreasing relative share of prestigious professional positions among graduate occupational destinations.

\section{Results}

\subsection{Educational expansion and graduates' occupational destinations}

Table 1 presents the distribution of occupational destinations among university graduates (CASMIN 3b) over time. We distinguish between occupational positions below the salariat class (intermediate and working classes, EGP III-VII) and four groups within the salariat class (EGP I and II): (1) technical experts, (2) managerial and administrative positions, (3) semiprofessions and (4) professions. The semi-professions comprise, for instance, artists, opticians, librarians, or interpreters. The professions include judges, attorneys, lawyers, doctors, dentists, vets, pharmacists, teachers, lecturers and professors, scientists and the clergy. They either require a state-certified licence ("Staatsexamen") or a postgraduate degree in order to reach the higher ranks of the civil service.

[Table 1]

Historically, university graduates predominantly entered the professions, more so for women (83\%) than for men (65\%). Between the mid-1970s and the mid-1990s, the proportion of graduates in the professions nearly halved for both sexes. While an increasing proportion is employed in technical or managerial salariat class positions, some graduates, particularly women, took work in intermediate and working-class positions (EGP III-VI). This confirms 
our assumption that university graduates were increasingly employed in non-professional (salariat class) positions over time. Since the mid-1990s, however, the declining share of university graduates working in the professions has halted. This coincides with the fact that higher education expansion almost came to a standstill in Germany from the mid-1990s onwards (see Table 2 in section 7.5).

\subsection{Trends in the association between educational attainment and occupational prestige}

Figure 1 shows changes in the proportion of variance explained $\left(\mathrm{R}^{2}\right)$ in occupational prestige for a model including only educational attainment and a model also including citizenship. Since both values are almost identical, controlling for citizenship does not make a difference to trends in the association between educational attainment and occupational prestige over time. Therefore we concentrate on the more parsimonious model in the following analyses.

[Figure 1]

The most salient change is the consistent decline in the association between the 1980s and mid-1990s for both sexes. The variance explained by educational attainment was reduced by almost 20 percentage points for men and almost 30 percentage points for women. From the end of the 1990s onwards, the association remained relatively constant for men and increased again slightly for women.

The declining association for both sexes in the 1980s and 1990s is in line with our hypothesis. However, we still do not know which developments are responsible for this reduction. According to our theoretical arguments, the explained variance became smaller because of a declining gap between university graduates and all other educational groups in terms of prestige and increasing prestige heterogeneity among graduates. 


\subsection{Trends in intergroup differences}

Figure 2 indicates the changes in average occupational prestige for the six different CASMIN educational groups. As expected, the most pronounced change is evident for male and female university graduates: on average, their occupational prestige decreased until the mid-1990s. Except for individuals in CASMIN 1ab, all men had somewhat decreasing average prestige scores across the 1980s. This hints at an oversupply of highly educated men and crowding-out processes from above in this period. Nevertheless, for both sexes, particularly women, the gap in average occupational prestige between university graduates and individuals with lower qualifications narrowed. Therefore, decreasing intergroup differences contribute to the declining predictability of occupational prestige by educational attainment.

[Figure 2]

\subsection{Trends in intragroup variation}

The second determinant of the association trend could be changes in intragroup variation, i.e. whether graduates with the same educational certificates became more or less similar with regards to occupational prestige over time. Figure 3 indicates the residual variation around the predicted prestige over time for each educational group. As assumed, the dispersion increased considerably among graduates, particularly among women. This growing within-group residual variance contributes to the decreasing predictive value of educational attainment with regards to occupational prestige. The sharply increasing heterogeneity among female university graduates may explain why the proportion of explained variance decreased more strongly among women than among men. From the mid-1990s onwards, however, residual variation among university graduates decreased again for both sexes. This coincides with the 
slightly increasing predictability of occupational prestige by educational attainment during this more recent period.

[Figure 3]

\subsection{Group composition shifts}

The third factor that could have affected the association is distributional change in the population's educational attainment. Table 2 shows the educational profile (in terms of six CASMIN levels) of our sample of labour market entrants over time. For both men and women, the expansion of higher education in terms of an increase in the proportion with CASMIN $3 \mathrm{ab}$ degrees clearly took place before the end of the 1990s in Germany. Since then, expansion among graduates has almost stopped for men and grown more slowly for women.

While higher education expansion increased the share of individuals whose prestige scores deviate more strongly from the grand mean (see Figure 2), it increases the share of individuals that are in heterogeneous groups (see Figure 3). Hence, higher education expansion should have increased the explained variance as well as the residual variance. Due to these countervailing effects, group composition shifts do not explain the decreasing predictability of occupational prestige by educational attainment.

[Table 2]

\subsection{Counterfactual analysis}

The decrease in the predictive value of educational attainment on occupational prestige can be attributed to changes among university graduates, i.e. decreasing average prestige and increasing heterogeneity. However, the mechanism behind these developments is still unclear. 
In order to test our hypothesis that the association declined because of compositional changes in graduate occupational destinations, we simulate some counterfactual scenarios. In the first scenario, we exclude overeducated graduates who are employed in working and intermediate class positions (EGP III-VII) at all points in time. Hence, we test whether increasing overeducation among graduates can explain their decreasing average prestige and increasing heterogeneity. In the second scenario, we exclude graduates working in the closed professions in all Microcensus years in our sample. This shows how the association between education and occupational prestige would have developed over time if professions, featuring high occupational closure, had never been career options.

[Figure 4]

Figure 4 compares trends in the predictive value of educational attainment among these two counterfactuals with the observed data for both sexes (trends in Figure 1). Unsurprisingly, excluding university graduates in occupational positions below the salariat class increases the predictability of occupational prestige by educational attainment in comparison to the real world. Since the decrease in explained variance is somewhat flatter under this scenario than in reality, the increase in overeducated university graduates over the 1980s (see again Table 1) accounts in part for the declining predictability of educational attainment on occupational prestige, more so for women than for men. However, we still see a substantial decline in the association in this counterfactual scenario for both sexes. Even assuming that all university graduates had entered 'appropriate' graduate occupations, the association between education and occupational prestige would have declined in any case. This confirms that the mechanism for changes in this association is independent of graduate returns in terms of accessing the salariat class. 
Simulating a world without the professions, the variance explained by educational attainment would have been much lower than in reality, in particular for women. Hence, if closed professions that are restricted to university graduates had never existed, the advantage among graduates in terms of social honour compared to groups with lower educational attainment would have clearly been less pronounced. Had the prestigious professional positions never existed, university graduates would have had about the same average occupational prestige as polytechnic graduates. This stresses the important role of the traditional professions for university graduate rewards in the labour market.

Over time, this counterfactual shows that for both sexes the predictive value of educational attainment on occupational prestige would have remained largely stable without the existence of the professions. This provides support for our hypothesis: the declining association between education and occupational prestige can, in fact, be attributed to compositional changes within university graduate occupational attainment during higher education expansion. The average occupational prestige of graduate jobs reduced over time and became increasingly heterogeneous simply because fewer graduates accessed the prestigious professions but found employment in new graduate occupations in the expanding technical and administrative/managerial segments.

\section{Summary and conclusion}

While classes capture differences in labour market positions in terms of economic rewards, occupational prestige is based on exclusiveness and monopolisation of goods and thus determined by occupational closure. This conceptual distinction leads to different theoretical implications for the relationship with educational attainment over time. The link between educational attainment and social class depends on the productivity value that employers attach to job applicants' educational attainment in the hiring process. By contrast, the relationship 
between education and occupational prestige is determined by the degree to which access to occupations is exclusively given to degree holders. Depending on the outcome, returns to education may have developed differently over time.

Empirically, the association between education and class destinations (measured in terms of EGP) has been found to be rather stable in Germany (Klein 2011). Regarding the association between education and occupational prestige, however, we hypothesised that it would inevitably decline over time. Over the course of higher education expansion an increasing share of university graduates was unable to gain access to the prestigious professions and mainly ended up in less prestigious occupational positions in the salariat class (EGP I and II). This compositional change reduced graduates' average prestige and increased their heterogeneity, leading to a decreasing predictability of occupational prestige by educational attainment.

The results provide evidence for our hypothesis. The association between educational attainment and occupational prestige decreased strongly in the phase of higher education expansion between the start of the 1980s and the mid-1990s. As expected, the gap in average occupational prestige between university graduates and individuals with lower educational attainment decreased and heterogeneity among graduates increased. Counterfactual scenarios show that an increase in the proportion of overeducated university graduates (working below the salariat class) cannot account for this decreasing association. Even assuming that all graduates were employed in 'appropriate' occupational positions, i.e. salariat class positions, the association would have, nevertheless, decreased. By contrast, assuming that professions never existed, it would have remained stable. This indicates that the declining association can be attributed to compositional changes in university graduate occupational destinations. During educational expansion the relative number of university graduates employed in salariat class positions (particularly administrative and managerial occupations) other than the professions increased. Since these free-market positions are less prestigious and more diverse than the 
professions, the association between educational attainment and occupational prestige inevitably declined. Even if employers continue to strongly rely on education in their hiring decisions such as in Germany, the value of a university degree in terms of social honour necessarily has to decline throughout higher education expansion.

Analysing changes in the relationship between educational attainment and occupational prestige relies on the assumption that prestige hierarchies are invariant through space and time (Treiman 1977; Nakao and Treas 1994; Hodge et al. 1964). This so-called 'Treiman Constant' is referred to as an empirical generalisation that may be 'the only universal sociologists have discovered' (Hout and DiPrete 2006: 3). However, based on a strictly Weberian interpretation, the prestige attached to occupations may change when the mechanisms supporting occupational closure change over time, e.g. in the extent to which occupations rely on credentialing. However, this does not invalidate our findings since professions in Germany clearly remain at the top of the hierarchy so long as access is bound to state-certified licences that can only be acquired via university education.

This paper has implications for analysing the returns to education and social stratification in general. First, it emphasises that trends in returns to education are dependent on the chosen outcome and its operationalisation (see also Van de Werfhorst 2007). Studies that deal with returns to education over time are urged to use a multidimensional concept of labour market outcomes in order to account for different aspects of labour market inequality. Apparently, social classes alone do not reveal the whole picture since they neglect structural or institutional barriers in the labour market. Occupational closure determines not only the level of prestige attached to occupations but also has a strong positive effect on wages (Bol 2014; Bol and Weeden 2012; Weeden 2002). In the class framework, the professions are equated with other (new emerging) high-skilled occupations in the salariat class. However, labour market positions in the salariat class are quite heterogeneous in terms of prestige (and other 
aspects such as wages) and have become more so over time. While a growing share of university graduates was absorbed by the expanding salariat class, gaining these positions today does not guarantee the same economic and social rewards as in former times. Due to this growing heterogeneity, it might be worthwhile to break down class destinations, particularly the salariat class, into occupations or occupational segments in order to detect potential inequalities in labour market rewards, employment relations or career prospects that are created in a systematic way at the occupational level (Brown 2013).

Second, the increasing heterogeneity among graduates in terms of labour market rewards potentially facilitates continued intergenerational social reproduction; in other words even though all HE entrants pursue a degree, students from a salariat class background may be more likely to choose programmes that lead to more rewarding occupational destinations than students from lower class backgrounds. In Germany, upper secondary school leavers from a higher social background more frequently choose fields of study such as medicine and law rather than humanities or social sciences compared to school leavers from lower social backgrounds, and, this pattern has remained largely stable over time (Reimer and Pollak 2010). Higher education expansion may lead to greater social fluidity in terms of class destinations (Breen 2010), but, at the same time, social inequalities would be 'effectively maintained' via horizontal choices in the education system (e.g. field of study, higher education institution) or extracurricular activities (Lucas 2001). Moreover, status groups may not only be identified via occupational closure but may also be grouped by the similarity of friendship patterns (Chan and Goldthorpe 2007). In contemporary societies, inequalities in terms of social honour may increasingly operate via these more informal and implicit social networks and thus should be increasingly focused on in future research. 


\footnotetext{
${ }^{1}$ Hence, the term 'professions' in this paper only refers to traditional professions with legal access boundaries. Contemporary research on professionals expands the focus and includes a broader range of expert or knowledgebased occupations (Gorman and Sandefur 2011).

${ }^{2}$ Weber (1972 [1922]: 203) explicitly refers to the guilds ('Zünfte') and educational requirements for modern civil servants ('Beamte') and white-collar employees ('Angestellte').

${ }^{3}$ Educational systems can, for instance, differ with regard to tracking, the curriculum, the certification of qualifications or formal entry rules to enter occupations. Labour markets may vary in the role of unions or professional organisations, the wage setting process or employment protection legislation (EPL).

${ }^{4}$ For the complete article see http://www.gesetze-im-internet.de/stgb/_132a.html (last access May 30, 2014).

${ }^{5}$ Another prominent example of occupational licensing is the German skilled trades where the Trade and Crafts code restricts self-employment in more than 40 trades to those who have gained the licence of a master craftsman (Hansen 2011; Bol 2014).

${ }^{6}$ Informal ways of restricting the number of students in professional studies are, for instance, long-term and effortful studies prior to attaining the final licence (e.g. in medicine). In law, job competition is intensified by a strict examination system, i.e. the average grade among graduates is worse than in other fields of study. In order
} 
to become a psychotherapist, graduates with a psychology degree need to gain additional training for three years (full-time) or five years (part-time) and bear the costs of the programme (20.000-40.000 €) themselves.

${ }^{7}$ Since the Microcensus does not provide information on the first job, labour market entry for individuals with different qualifications was approximated with typical graduation ages.

${ }^{8}$ For details on the operationalisation of the EGP class schema see Klein (2011). 


\section{References}

Abbott A (1988) The System of Professions: An Essay on the Division of Expert Labor. Chicago: The University of Chicago Press.

Autor DH, Levy F and Murnane RJ (2003) The Skill Content of Recent Technological Change: An Empirical Exploration. The Quarterly Journal of Economics 118(4): 1279-1333.

Becker R (1993) Staatsexpansion und Karrierechancen: Berufsverläufe im öffentlichen Dienst und in der Privatwirtschaft. Frankfurt am Main; New York: Campus Verlag.

Blau PM and Duncan OD (1967) The American Occupational Structure. New York: Wiley.

Blossfeld H-P (1985) Bildungsexpansion und Berufschancen: Empirische Analysen zur Lage der Berufsanfänger in der Bundesrepublik. Frankfurt am Main: Campus.

Bol T (2014) Economic Returns to Occupational Closure in the German Skilled Trades. Social Science Research 46: 9-22.

Bol T and Weeden KA (2012) Occupational Closure and Wage Inequality in Germany and the United Kingdom. Working Paper, Amsterdam Center of Inequality Studies, University of Amsterdam.

Brauns H and Steinmann S (1999) Educational Reform in France, West- Germany, and the United Kingdom. Updating the CASMIN Educational Classification. ZUMA-Nachrichten 44: 7-45.

Breen R (2004) Social Mobility in Europe. Oxford: Oxford University Press.

Breen R (2010) Educational Expansion and Social Mobility in the 20th Century. Social Forces 89(2): 365-388.

Brown DK (2001) The Social Sources of Educational Credentialism: Status Cultures, Labor Markets, and Organizations. Sociology of Education 74(Extra Issue): 19-34.

Brown P (2013) Education, Opportunity and the Prospects for Social Mobility. British Journal of Sociology of Education 34(5-6): 678-700.

Collins R (1979) The Credential Society: An Historical Sociology of Education and Stratification. New York: Academic Press.

Collins R (2004) Schließungsprozesse und die Konflikttheorie der Professionen. In: Mackert J (ed.) Die Theorie sozialer Schließung. Tradition, Analysen, Perspektiven. Wiesbaden: VS Verlag für Sozialwissenschaften, pp. 67-86.

Dore RP (1976) The Diploma Disease: Education, Qualification and Development. Berkeley: University of California Press.

Elias P and Purcell K (2004) Is Mass Higher Education Working? Evidence From The Labour Market Experiences of Recent Graduates. National Institute Economic Review 190(1): 60-74.

Fischer W and Lundgreen P (1975) The Recruitment and Training of Administrative and Technical Personell. In: Tilly C (ed.) The Formation of National States in Western Europe. Princeton: Princeton University Press, pp. 456-561.

Freidson E (1994) Professionalism Reborn. Theory, Prophecy and Policy. Cambridge: Polity Press.

Frietsch R and Wirth H (2001) Die Übertragung der Magnitude-Prestigeskala von Wegener auf die KldB. ZUMA-Nachrichten 48: 139-163.

Gangl M (2003) Explaining Change in Early Career Outcomes: Labour Market Conditions, Educational Expansion, and Youth Cohort Sizes. In: Müller W and Gangl M (eds.) Transitions from Education to Work in Europe: The Integration of Youth into EU Labour Markets. Oxford: Oxford University Press, pp. 251-276.

Goldthorpe JH (2007) Social Class and the Differentiation of Employment Contracts. In: Goldthorpe JH (ed.) On Sociology. Volume Two: Illustration and Retrospect. Stanford: Stanford University Press, pp. 101-124.

Gorman EH and Sandefur RL (2011) "Golden Age," Quiescence and Revival: How the Sociology of Professions Became the Study of Knowledge-Based Work. Work and Occupations 38(3): 275-302. 
Hansen H (2011) Rethinking Certification Theory and the Educational Development of the United States and Germany. Research in Social Stratification and Mobility 29(1): 31-55.

Hirsch F (1977) Social Limits to Growth. London: Routledge and Kegan Paul.

Hodge RM, Siegel PM and Rossi PM (1964) Occupational Prestige in the United States: 19251963. American Journal of Sociology 70: 286-302.

Hout M and DiPrete TA (2006) What We Have Learned: RC 28's Contribution to Knowledge About Social Stratification. Research in Social Stratification and Mobility 24(1): 1-20.

Jackson M, Goldthorpe JH and Mills C (2005) Education, Employers and Class Mobility. Research in Social Stratification and Mobility 23: 3-33.

Klein M (2011) Trends in the association between educational attainment and class destinations in West Germany: Looking inside the service class. Research in Social Stratification and Mobility 29(4): 427-444.

Kleiner M (2006) Licensing Occupations: Ensuring Quality or Restricting Competition. Kalamazoo: W.E. Upjohn Institute for Employment Research.

Kleiner M and Krueger AB (2010) The Prevalence and Effects of Occupational Licensing. British Journal of Industrial Relations 48(4): 676-687.

Lane C, Potton M and Littek W (2002) The Professions between State and Market. A CrossNational Study of Convergence and Divergence. European Societies 4(2): 235-260.

Law MT and Sukkoo K (2005) Specialization and Regulation: The Rise of Professionals and the Emergence of Occupational Licensing Regulations. The Journal of Economic History 65(3): 723-756.

Lechert Y, Schroedter J and Lüttinger P (2006) Die Umsetzung der Bildungsklassifikation CASMIN für die Volkszählung 1970, die Mikrozensus-Zusatzerhebung 1971 und die Mikrozensen 1976-2004. ZUMA Methodenbericht 2006/12 ZUMA, Mannheim.

Leuze K (2007) What Makes for a Good Start? Consequences of Occupation-Specific Higher Education for Career Mobility. International Journal of Sociology 37(2): 29-53.

Lucas SR (2001) Effectively Maintained Inequality: Education Transitions, Track Mobility, and Social Background Effects. American Journal of Sociology 106(6): 1642-1690.

Marsden D (1990) Institutions and Labour Mobility: Occupational and Internal Labour Markets in Britain, France, Italy and West Germany. In: Brunetta R and Dell'Aringa C (eds.) Labour Relations and Economic Performance. Venedig: The Macmillan Press, pp. 414-438.

Müller W (2001) Zum Verhältnis von Bildung und Beruf in Deutschland. In: Berger PA and Konietzka D (eds.) Die Erwerbsgesellschaft - Neue Ungleichheiten und Unsicherheiten. Opladen: Leske + Budrich, pp. 29-64.

Nakao K and Treas J (1994) Updating Occupational Prestige and Socioeconomic Scores: How the New Measures Measure Up. Sociological Methodology 24: 1-72.

Neal M and Morgan J (2000) The Professionalization of Everyone? A Comparative Study of the Development of the Professions in the United Kingdom and Germany. European Sociological Review 16(1): 9-26.

OECD (2013) Education at a Glance. Paris: OECD.

Parkin F (1979) Marxism and Class Theory: A Bourgeois Critique. London: Tavistock Publications.

Reimer D and Pollak R (2010) Educational Expansion and Its Consequences for Vertical and Horizontal Inequalities in Access to Higher Education in West Germany. European Sociological Review 26(4): 415-430.

Schubert F and Engelage S (2006) Bildungsexpansion und berufsstruktureller Wandel. In: Hadjar A and Becker R (eds.) Die Bildungsexpansion - erwartete und unerwartete Folgen. Wiesbaden: VS Verlag für Sozialwissenschaften, pp. 93-121.

Sørensen AB (1977) The Structure of Inequality and the Process of Attainment. American Journal of Sociology 42(6): 965-978. 
Sørensen AB (1979) A Model and a Metric for the Analysis of the Intragenerational Status Attainment Process American Journal of Sociology 85(2): 361-384.

Sørensen AB (2000) Employment relations and class structure. In: Crompton R, Devine F, Savage M and Scott J (eds.) Renewing Class Analysis. Oxford: Blackwell Publishers, pp. 1642.

Timmermans S (2008) Professions and Their Work: Do Markets Shelters Protect Professional Interests? Work and Occupations 35: 164-188.

Treiman DJ (1977) Occupational Prestige in Comparative Perspective. New York: Academic Press.

Van de Werfhorst HG (2007) Scarcity and Abundance: Reconciling Trends in the Effects of Education on Social Class and Earnings in Great Britain 1972-2003. European Sociological Review 23(2): 239-261.

Weber M (1972 [1922]) Wirtschaft und Gesellschaft. Tübingen: Mohr.

Weeden KA (2002) Why Do Some Occupations Pay More Than Others? Social Closure and Earnings Inequality in the United States. American Journal of Sociology 108(1): 55-101.

Weeden KA and Grusky DB (2005) The Case for a New Class Map. American Journal of Sociology 111(1): 141-212.

Wegener B (1985) Gibt es Sozialprestige? Zeitschrift für Soziologie 14(3): 209-235.

Zhou X (2005) The Institutional Logic of Occupational Prestige Ranking: Reconceptualization and Reanalyses. American Journal of Sociology 111(1): 90-140. 
Table 1 Graduate occupational destinations at labour market entry (in per cent)

\begin{tabular}{lccccc}
\hline Men & III-VII & $\begin{array}{c}\text { I/II } \\
\text { technical }\end{array}$ & $\begin{array}{c}\text { I/II admin./ } \\
\text { managerial }\end{array}$ & $\begin{array}{c}\text { I/II semi- } \\
\text { professions }\end{array}$ & $\begin{array}{c}\text { I/II } \\
\text { professions }\end{array}$ \\
$1976-1980$ & 8 & 13 & 9 & 6 & 65 \\
$1982-1987$ & 13 & 18 & 9 & 7 & 53 \\
$1989-1993$ & 15 & 27 & 14 & 8 & 37 \\
$1995-1999$ & 14 & 30 & 16 & 7 & 33 \\
$2000-2004$ & 14 & 29 & 19 & 7 & 32 \\
$2005-2008$ & 11 & 26 & 19 & 7 & 36 \\
\hline Women & III-VII & I/II & I/II admin./ & I/II semi- & I/II \\
& & technical & management & professions & professions \\
$1976-1980$ & 6 & 1 & 2 & 3 & 83 \\
$1982-1987$ & 11 & 4 & 3 & 6 & 71 \\
$1989-1993$ & 18 & 8 & 6 & 10 & 53 \\
$1995-1999$ & 19 & 9 & 8 & 11 & 45 \\
$2000-2004$ & 16 & 10 & 10 & 9 & 48 \\
$2005-2008$ & 12 & 8 & 11 & 8 & 53 \\
\hline
\end{tabular}

Source: German Microcensus, Scientific-Use-Files 1976-2008 
Table 2 Distribution of educational attainment (in per cent)

\begin{tabular}{lcccccc}
\hline Men & $1 \mathrm{ab}$ & $1 \mathrm{c}$ & $2 \mathrm{ab}$ & $2 \mathrm{c}$ & $3 \mathrm{a}$ & $3 \mathrm{~b}$ \\
$1976-1980$ & 13 & 50 & 19 & 4 & 5 & 9 \\
$1982-1987$ & 12 & 42 & 23 & 7 & 6 & 10 \\
$1989-1993$ & 10 & 34 & 26 & 11 & 8 & 12 \\
$1995-1999$ & 10 & 25 & 22 & 14 & 12 & 17 \\
$2000-2004$ & 12 & 21 & 24 & 14 & 13 & 17 \\
$2005-2008$ & 13 & 21 & 24 & 15 & 11 & 16 \\
\hline Women & $1 \mathrm{ab}$ & $1 \mathrm{c}$ & $2 \mathrm{ab}$ & $2 \mathrm{c}$ & $3 \mathrm{a}$ & $3 \mathrm{~b}$ \\
$1976-1980$ & 20 & 43 & 28 & 3 & 2 & 5 \\
$1982-1987$ & 17 & 29 & 36 & 8 & 2 & 8 \\
$1989-1993$ & 12 & 22 & 37 & 16 & 4 & 10 \\
$1995-1999$ & 12 & 17 & 31 & 20 & 7 & 14 \\
$2000-2004$ & 12 & 13 & 31 & 19 & 8 & 16 \\
$2005-2008$ & 12 & 11 & 30 & 22 & 7 & 17 \\
\hline Source: German Microcensus, Scientific-Use-Files 1976-2008. & &
\end{tabular}


Figure 1 Proportion of variance explained by educational attainment

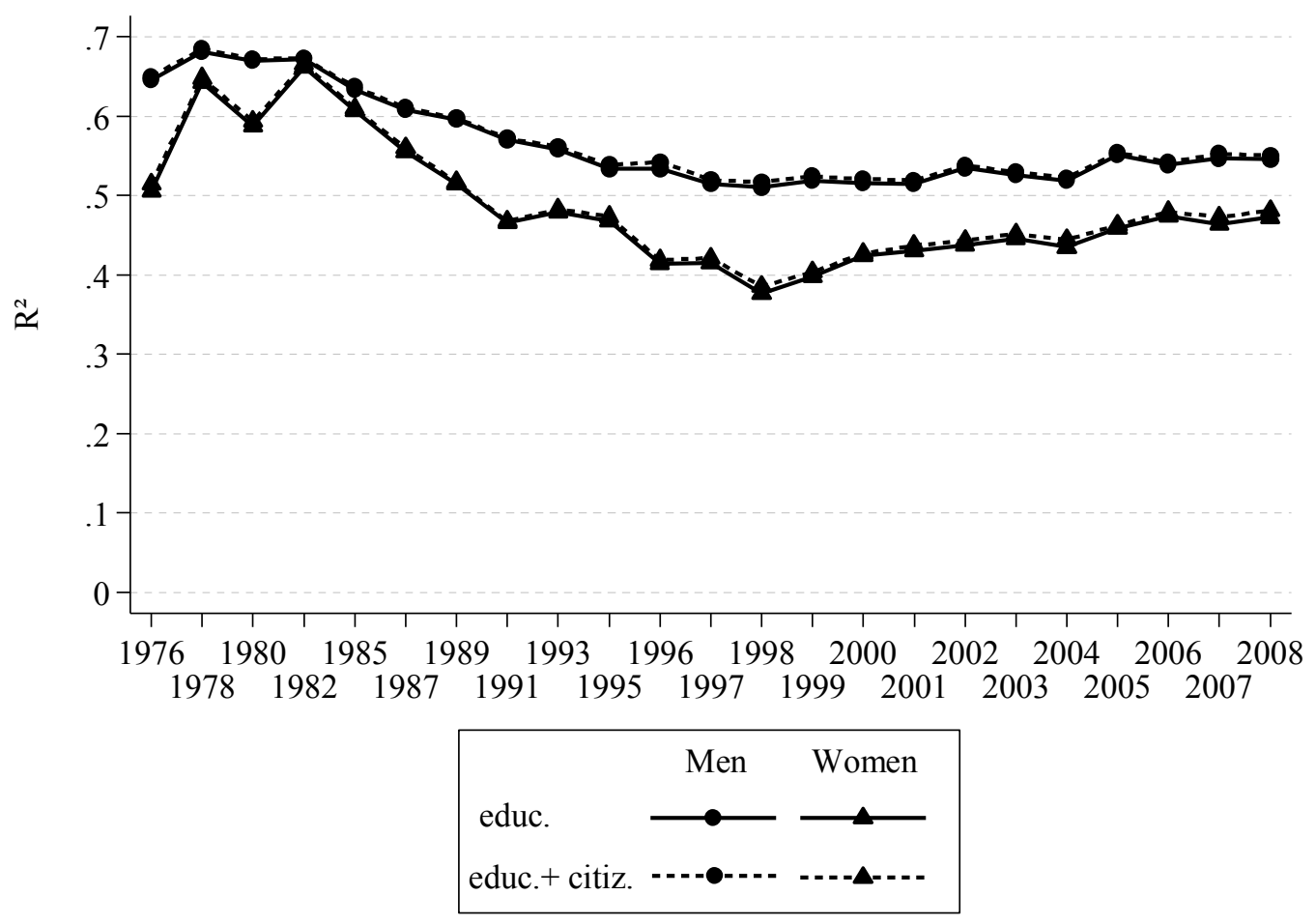

Source: German Microcensus, Scientific-Use-Files 1976-2008. 
Figure 2 Estimated occupational prestige by educational attainment
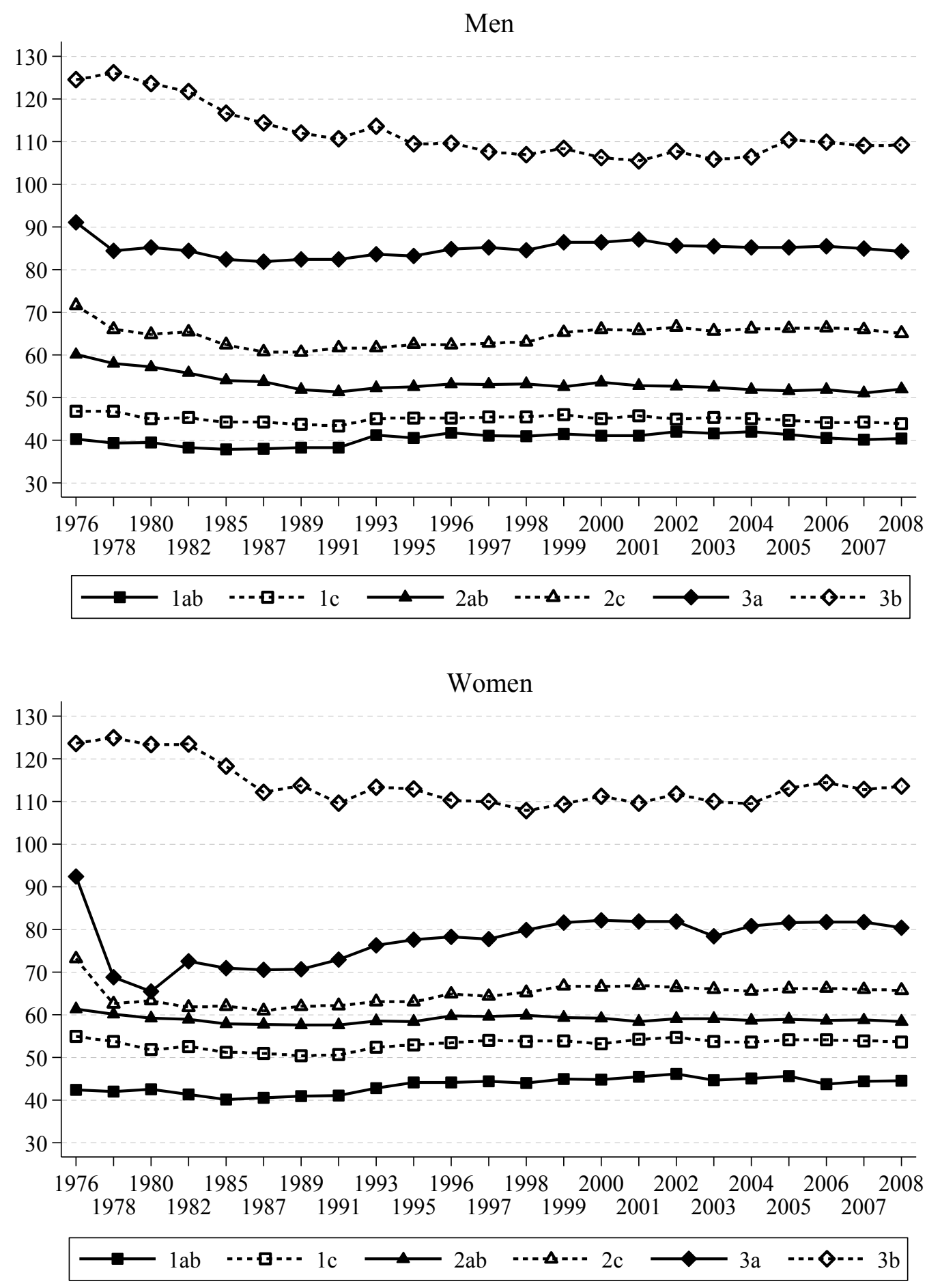

Source: German Microcensus, Scientific-Use-Files 1976-2008. 
Figure 3 Residual variation by educational attainment
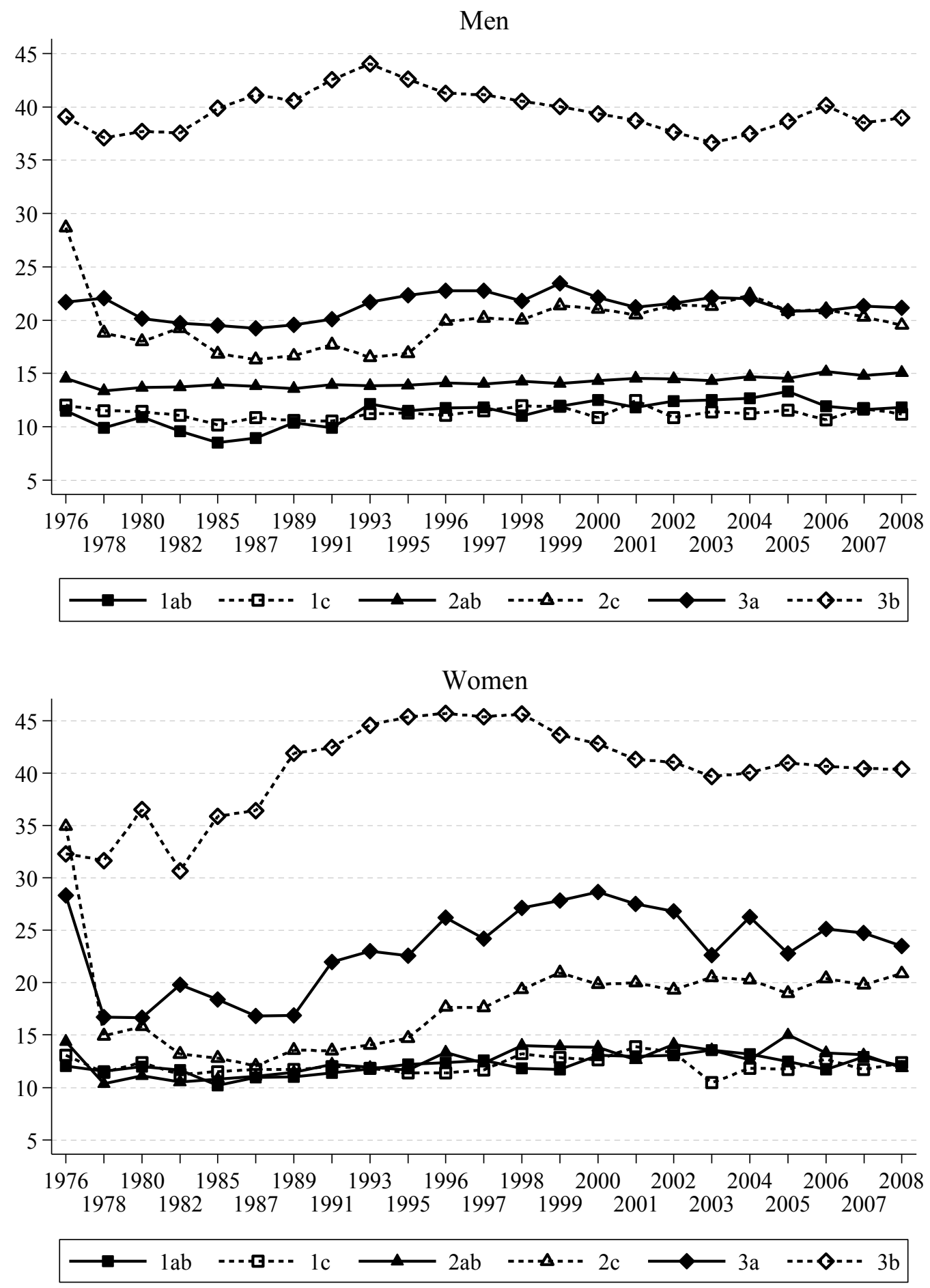

Source: German Microcensus, Scientific-Use-Files 1976-2008. 
Figure 4 Counterfactuals and the proportion of variance explained by education
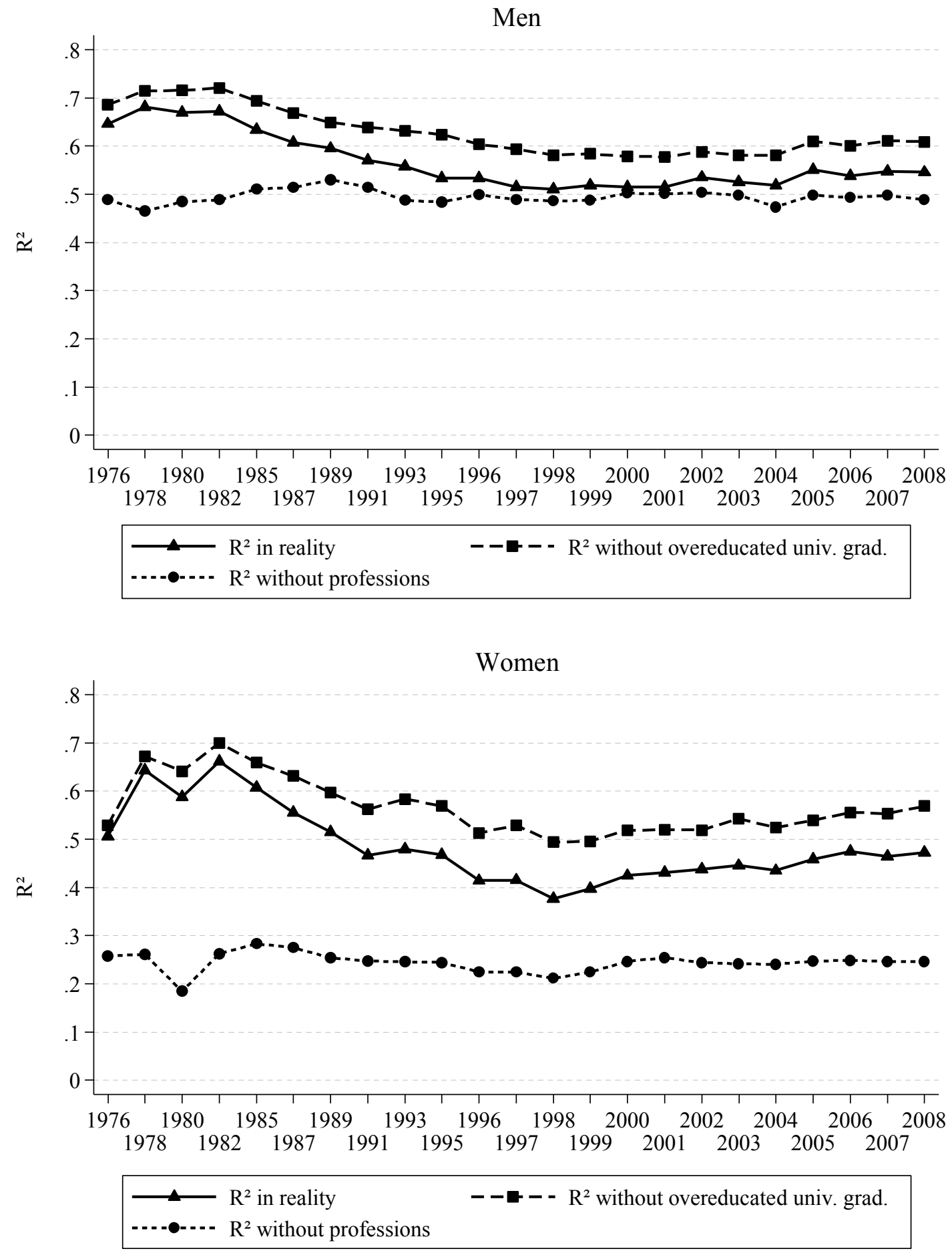

Source: German Microcensus, Scientific-Use-Files 1976-2008. 


\section{Biography}

Markus Klein is AQMeN (applied quantitative methods network) research fellow in the research strand 'Education and Social Stratification' in the University of Edinburgh. Previously, he was employed as research associate in the Mannheim Centre for European Social Research (MZES) and completed his doctoral studies in the Graduate School of Economic and Social Sciences, University of Mannheim. His research interests include social stratification and social mobility, educational inequality and school-to-work transitions.

\section{Acknowledgements}

For valuable comments on earlier versions of this article I would like to thank Walter Müller, Yossi Shavit, Emer Smyth and two anonymous reviewers. Institutional support from the Mannheim Centre for European Social Research, University of Mannheim, is gratefully acknowledged.

\section{Funding}

This research received funding from the German Federal Ministry of Education and Research, grant 01JG0926. 